\title{
Methods of Pollination Influencing Fruit Development Stages of Exotic Apple Cultivars at High Altitudes of Kashmir Valley
}

\author{
Bilal A. Pandit ${ }^{*}$, M. Ashraf Bhat ${ }^{2}$, Mumtaz A. Ganie ${ }^{3}$, T. Rasool $^{3}$ and Parmeet Singh ${ }^{4}$ \\ ${ }^{1}$ Department of Horticulture, ${ }^{3}$ Department of Soil Science, KVK Shopian, \\ SKUAST- Kashmir-190025, India \\ ${ }^{2}$ Division of Plant Breeding and Genetics, Faculty of Agriculture Wadura- \\ Sopore-190025, India \\ ${ }^{4}$ KVK Shopian, SKUAST- Kashmir-190025, India \\ *Corresponding author
}

\section{Keywords \\ Pollination methods, Fruit set, Fruit drop, Maturity and apple \\ Article Info \\ Accepted: \\ 16 August 2018 \\ Available Online: \\ 10 September 2018}

\section{A B S T R A C T}

The present investigation entitled "Methods of Pollination Influencing Fruit Development Stages of Exotic Apple Cultivars at High Altitudes of Kashmir Valley" was carried out at "Advanced Centre for Horticulture Development Zainapora, Shopian" during 2012 and 2013. The experimental material (varieties) i.e. treatments were Gala Mast, Royal Gala, Early Red One, Law Red Rome, Scarlet Spur, Oregon Spur, Braeburn, Ginger Gold, Red Gravenstein, Golden Delicious and Red Gold. Observations were made to evaluate the difference in response of these Washington brought genotypes under Kashmir valley and their fruitfulness for horticulture industry. Among the methods, natural selfing recorded the highest initial fruit set $1.48 \%$ in Red Gold as compared to zero percent recorded in some other varieties. Under open pollination method, the initial fruit set was highest 88.35, and 87.00 percent, and final $33.30 \%$, and $34.41 \%$ in Red Gold cultivar. The lowest initial fruit set 65.77 and 67.71 percent and final fruit set (14.32 and 17.24\%) observed in Red Gravenstein and Ginger Gold. The maximum fruit drop (79.64 and 77.56 percent) observed in the cultivar Scarlet spur and Ginger Gold. The minimum fruit drop 62.57 and 61.16 per cent recorded in Golden Delicious followed by 62.30 and 60.44 per cent in Red Gold. In fruit maturity, the cultivar Golden Delicious took significantly more number of 185 and 183 days after full bloom (DAFB) to reach the harvestable stage. Red Gravenstein took minimum number of days ( 95 and 96 DAFB) to reach harvestable maturity during both years, respectively.

\section{Introduction}

The apple is a typical temperate fruit, which performs best in regions where the trees experience uninterrupted winter rest. Kronenberg (1979) suggested a chilling requirement of 1000 hours at below $7^{\circ} \mathrm{C}$. However, some cultivars require very low (250 hours) chilling and some late flowering cultivars have very high chilling requirements (1400-1600 hours). Abundant sunshine is important for good colour development in 
growing apples and intensity of solar radiation determines the economic yield. Apple trees are particularly sensitive to low moisture conditions. Water stress during growing season reduces number and size of fruits and increases June drop (Goode, 1975). A welldrained slightly acidic (about $\mathrm{pH}$ 6.5-6.7) loam soil with good depth considered ideal for apple cultivation. The best growth and productivity of apple found on soils with good drainage and aeration.

Apple has a gametophytically determined selfincompatibility (SI) system (Westwood, 1993; Alston, 1996; Kao and McCubbin, 1996). As a result, apple cultivars depend partially or totally on the flowering phenology of a compatible pollinizer (a tree acting as pollen donor to the main cultivar) and on bee mobility between the compatible varieties in order to achieve desirable fruit-set and yield. The incompatibility is the most widespread system preventing the pollination by its own or relative pollen. SI systems are genetically controlled mechanisms that inhibit fertilization by self-pollen or pollen from closely related plants (De Nettancourt, 2001). Out crossing enhanced in SI species by effectively dividing the population into compatibility groups, or mating types, where within-group crosses are sterile but crosses between groups are fertile (Darwin, 1877). It is well established that fruit set and yield are strongly dependent on genotype and genotype interactions for many important fruit crops within the family of Rosaceae, such as apples, pears, cherries, apricots and almonds. In these well-known crops, reproduction is governed by a gametophytic self-incompatibility system associated with stylar RNases (Tao et al., 1997, 1999). At least in apples these RNases express in the pistil, along the pollen tube growth path (Certal et al., 1999).

In a crop like apple, commercial pollination is of utmost significance and its proportion and magnitude primarily based upon appropriate selection of varieties. In a short span of about fifty years, apple cultivation has totally revolutionized the status of the farming community. Both production and productivity in the early phase of apple cultivation showed marked increasing trend but in recent times despite increase in area brought under apple cultivation, corresponding increase in productivity is lacking. A number of factors are responsible, major being very old and declining orchards, insufficient pollinizers, poor selection, and improper placement of pollinizers. Pollination is the sexual portion of a tree's life cycle and involves the integration of several biological and physical factors, including cultivar compatibility, synchronous blooming, insect abundance and proper weather conditions. If any one of these components is missing or limiting, crop yield and quality could be affected. All apple cultivars require cross-pollination to ensure commercial crops. Varieties differ in their self-fruitfulness. For example, Golden Delicious is considered partially self-fruitful, while Delicious largely is self-unfruitful. Most of the apple varieties are self-unfruitful and cannot produce fruit if fertilized by their own pollen and hence require some other compatible cultivar for cross pollination in order to set a good crop. Without pollination, fertilization and formation of zygote, the ovule, ovary and associated tissues do not develop further and the flower usually abscises resulting in poor fruit production. There are some 2000 known varieties of apple (Zohary and Hopf, 2000), of which the chance seedling "Golden Delicious" is economically the most important today.

Apple industry of Jammu and Kashmir State was revolutionized with the introduction of Delicious group, which accounts for about 60 per cent of the total apple production. Fruit industry has become back bone of rural economy and nearly four million people are 
directly or indirectly involved with this industry, but due to the monoculture, economic returns of the growers have not grown as per expectations. Therefore, stress is being laid on increasing the compatible varietal spectrum of fruit crops particularly apple. Lately state Horticulture Department has introduced some exotic cultivars of apple, which are in bearing at "Advanced Centre for Horticulture Development Zainapora, Shopian" Jammu and Kashmir, India. Some of these newly introduced varieties have been found to hold promise in terms of productivity, quality and performance under valley conditions. The State Horticulture Department has now started supplying the planting material of these varieties to the farmers of the valley. Of many factors, affecting the fruit production, pollination is of serious importance. It is most critical and complex part of the apple production. Although most of these apple varieties produce abundant bloom but their pollination, status is still unknown as no systematic study has been conducted under the valley conditions so far. Therefore division of fruit science faculty of horticulture SKUAST-K has organized a research programme on "Different Modes of Pollination Influencing Fruit Set and Drop of Exotic Apple Cultivars at High Altitudes of Kashmir Valley" to work out the most effective method of pollination for commercial fruiting of these cultivars.

\section{Materials and Methods}

The present investigation entitled "Methods of Pollination Influencing Fruit Development Stages of Exotic Apple Cultivars at High Altitudes of Kashmir Valley" conducted at 'Advanced Centre for Horticulture Development Zainapora, Shopian Jammu and Kashmir during 2012 and 2013. Full bearing exotic apple cultivars, uniform in age selected for experimentation in apple orchard. The orchard had proper air drainage situated at an altitude of $1600 \mathrm{~m}$ above msl. The soil was moderately deep, having medium fertility status. The soil texture of the experimental farm was sandy loam having soil $\mathrm{pH}$ 6.9, average organic matter, poor phosphorus, normal nitrogen and potassium content. The trees were spaced at $4 \mathrm{~m} \times 4 \mathrm{~m}$ distance and regularly weeded. Fertilizers applied as per schedule and other recommended practices for apple cultivation followed as per package. The experiment laid in randomized block design with eleven treatments and three replications. Eleven exotic genotypes of apple uniform in age were used for experimentation. Single tree in each variety constituted an experimental unit and each cultivar was replicated three times. The eleven genotypes used were Gala Must, Royal Gala, Early Red One, Law Red Rome, Scarlet Spur, Oregon Spur, Braeburn, Ginger Gold, Red Gravenstein, Golden Delicious and Red Gold. The phenological stages observed visually when the buds started showing the respective stages like, Selfpollination three branches on three sides of every experimental tree having healthy flowers tagged after counting the flowers and bagged. The bagging done on unopened flowers and left as such for natural selfpollination. For open pollination, three branches on three sides of every tagged tree of each cultivar having healthy flowers tagged after counting the flowers. They flowers left as such for open pollination. For initial fruit set percent, twenty days after cross pollination, fruit set on the basis of total number of flowers pollinated under different modes of pollination was recorded. The initial fruit set percent worked out by dividing the number of flowers pollinated to the number of fruits set multiplied by 100. Fruit drop percent calculated by the fruits dropped after initial fruit set were counted and the percentage of fruit drop worked out. The fruit drop was determined by dividing the number of fruits initially set to the number of fruits retained after subtracting final fruit set from initial fruit 
set and multiplied by 100 . Final fruit set was calculated by counting the number of fruits that were carried to maturity and dividing them by the number of flower buds selected and bagged for pollination. Fruit maturity the date of harvesting was recorded when fruit had attained proper size and developed colouration.

\section{Results and Discussion}

\section{Initial fruit set by self-pollination}

It is evident from the results given in Table 1 that there were non-significant differences in the fruit set of various exotic cultivars during the years of study. The fruit set was highest 1.48 per cent in Red Gold followed by Golden Delicious $(1.29 \%$ ) and minimum zero percent recorded in Royal Gala, Early Red One, Scarlet spur, Ginger Gold and Red Gravenstein. An interesting trend came into notice was that some of the varieties showed more or less fruits set $(0.37$ to $1.48 \%)$ while as none of the fruits set in other varieties during both the years, which supports the hypothesis of self-incompatibility in apples.

\section{Initial fruit set (\%) under open pollination}

The collected observatory data in the open pollination penned down in Table 2 reveals that initial fruit set was highest 88.35 and 87.00 per cent in Red Gold cultivar followed by Law Red Rome and Golden Delicious, which recorded 86.04 and 86.16 per cent initial fruit set during the years 2013 and 2014, respectively. Moreover, the lowest initial fruit set 65.77 and 67.71 per cent noticed in the cultivar Red Gravenstein that followed 69.78 and 71.62 per cent in the cultivar Early Red One during 2013 and 2014, respectively. The pooled data revealed that there were significant differences between the varieties except Law Red Rome and Oregon spur that showed non-significant difference.

\section{Final fruit set (\%) under open pollination}

The relevant data with respect to final fruit set recorded in (Table 3) open pollination of exotic cultivars during 2013 and 2014. It is evident from the data that the highest final fruit set (33.30 and $34.41 \%$ ) noticed in Red Gold cultivar followed by Golden Delicious (31.51 and 33.46\%) and Law Red Rome (29.46 and $31.57 \%$ ) during the years of study. The minimum final fruit set (14.32 and $17.24 \%$ ) observed in Ginger Gold followed by Scarlet spur (16.47 and 18.26\%) during the years of study. The pooled data also recorded the similar trend as described above, however there were significant differences when all these varieties compared with each other.

\section{Fruit drop (percentage)}

The relevant data observed with respect to fruit drop under open pollination is documented in Table 4. It is vivid from the data that maximum fruit drop $(79.64 \%)$ was observed in the cultivar Scarlet spur followed by Ginger Gold (73.49 \%) during year 2013 . During 2014 year, the maximum fruit drop $(77.56 \%)$ noticed in Ginger Gold followed by Scarlet spur $(74.99 \%)$. The minimum fruit drop 62.57 and 61.16 per cent recorded in Golden Delicious followed by 62.30 and 60.44 per cent in the Red Gold during 2013 and 2014 , respectively. The pooled data reflected a significant difference when compared the data of these varieties with each other except between Red Gold and Golden Delicious varieties, which were at par with each other.

\section{Fruit maturity of exotic apple cultivars}

The perusal of data reveals, the cultivar Golden Delicious took significantly more number of 185 and 183 days after full bloom (DAFB) to reach the harvestable stage followed by 164 and 167 (DAFB) taken by the cultivar Law Red Rome (Table 5). 
Table.1 Fruit set (\%) under natural self-pollination of exotic apple cultivars

\begin{tabular}{|l|c|c|c|}
\hline \multicolumn{1}{|c|}{ Genotypes } & $\mathbf{2 0 1 2}$ & $\mathbf{2 0 1 3}$ & Pooled \\
\hline Gala Must & $0.74(1.30)$ & $0.37(1.15)$ & $0.55(1.22)$ \\
\hline Royal Gala & $0.00(1.00)$ & $0.00(1.00)$ & $0.00(1.00)$ \\
\hline Early Red One & $0.00(1.00)$ & $0.00(1.00)$ & $0.00(1.00)$ \\
\hline Law Red Rome & $1.11(1.41)$ & $1.11(1.41)$ & $1.11(1.41)$ \\
\hline Scarlet spur & $0.00(1.00)$ & $0.00(1.00)$ & $0.00(1.00)$ \\
\hline Oregon spur & $0.37(1.15)$ & $0.37(1.15)$ & $0.37(1.15)$ \\
\hline Braeburn & $0.74(1.30)$ & $0.37(1.15)$ & $0.55(1.22)$ \\
\hline Ginger Gold & $0.00(1.00)$ & $0.00(1.00)$ & $0.00(1.00)$ \\
\hline Red Gravenstein & $0.00(1.00)$ & $0.00(1.00)$ & $0.00(1.00)$ \\
\hline Golden Delicious & $1.48(1.52)$ & $1.11(1.41)$ & $1.29(1.47)$ \\
\hline Red Gold & $1.48(1.52)$ & $1.48(1.52)$ & $\mathbf{0 . 2 9}$ \\
\hline \multicolumn{1}{|c|}{ CD (5\%) } & NS & NS & $(1.52)$ \\
\hline
\end{tabular}

Square root transformation values given in parentheses

Table.2 Initial fruit set (\%) under open pollination of exotic apple cultivars

\begin{tabular}{|l|c|c|c|}
\hline \multicolumn{1}{|c|}{ Genotypes } & 2012 & 2013 & Pooled \\
\hline Gala Must & $76.74(8.81)$ & $79.76(8.98)$ & $78.25(8.90)$ \\
\hline Royal Gala & $73.02(8.60)$ & $76.65(8.81)$ & $74.83(8.70)$ \\
\hline Early Red One & $69.78(8.41)$ & $71.62(8.52)$ & $70.70(8.46)$ \\
\hline Law Red Rome & $86.04(9.32)$ & $83.58(9.197)$ & $84.81(9.26)$ \\
\hline Scarlet spur & $80.93(9.05)$ & $82.03(9.11)$ & $81.48(9.08)$ \\
\hline Oregon spur & $83.80(9.20)$ & $85.03(9.27)$ & $84.41(9.24)$ \\
\hline Braeburn & $81.12(9.06)$ & $82.88(9.15)$ & $82.00(9.11)$ \\
\hline Ginger Gold & $73.94(8.65)$ & $76.83(8.82)$ & $75.38(8.73)$ \\
\hline Red Gravenstein & $65.77(8.17)$ & $67.71(8.28)$ & $66.74(8.23)$ \\
\hline Golden Delicious & $84.20(9.23)$ & $86.16(9.33)$ & $85.18(9.28)$ \\
\hline Red Gold & $88.35(9.45)$ & $87.00(9.38)$ & $87.68(9.41)$ \\
\hline \hline \multicolumn{1}{|c|}{ CD (5\%) } & $\mathbf{0 . 1 3}$ & $\mathbf{0 . 1 1}$ & $\mathbf{0 . 8 4}$ \\
\hline
\end{tabular}

Square root transformation values given in parentheses

Table.3 Final fruit set (\%) of exotic apple cultivars under open pollination

\begin{tabular}{|l|c|c|c|}
\hline \multicolumn{1}{|c|}{ Genotypes } & 2012 & 2013 & Pooled \\
\hline Gala Must & $28.32(5.32)$ & $29.72(5.45)$ & $29.02(5.38)$ \\
\hline Royal Gala & $25.76(5.07)$ & $27.46(5.24)$ & $26.61(5.15)$ \\
\hline Early Red One & $23.85(4.88)$ & $20.18(4.49)$ & $24.28(4.92)$ \\
\hline Law Red Rome & $29.46(5.42)$ & $31.57(5.61)$ & $30.51(5.52)$ \\
\hline Scarlet spur & $16.47(4.17)$ & $18.26(4.38)$ & $17.36(4.28)$ \\
\hline Oregon spur & $24.64(4.96)$ & $26.33(5.13)$ & $25.48(5.04)$ \\
\hline Braeburn & $25.76(5.07)$ & $27.46(5.24)$ & $26.61(5.15)$ \\
\hline Ginger Gold & $14.32(3.90)$ & $17.24(4.27)$ & $15.78(4.08)$ \\
\hline Red Gravenstein & $20.58(4.53)$ & $22.65(4.75)$ & $21.61(4.64)$ \\
\hline Golden Delicious & $31.51(5.61)$ & $33.46(5.78)$ & $32.49(5.70)$ \\
\hline Red Gold & $33.30(5.77)$ & $34.41(5.86)$ & $33.86(5.81)$ \\
\hline \multicolumn{1}{|c|}{ CD (5\%) } & $\mathbf{0 . 2 6}$ & $\mathbf{0 . 1 8}$ & $\mathbf{0 . 1 5}$ \\
\hline
\end{tabular}

Square root transformation values given in parentheses 
Table.4 Fruit drop (\%) under open pollination of exotic apple cultivars

\begin{tabular}{|l|c|c|c|}
\hline \multicolumn{1}{|c|}{ Genotypes } & Year 2012 & Year 2013 & Pooled \\
\hline Gala Must & 63.09 & 62.73 & 62.91 \\
\hline Royal Gala & 64.72 & 64.17 & 64.44 \\
\hline Early Red One & 65.82 & 71.82 & 68.82 \\
\hline Law Red Rome & 65.76 & 62.23 & 63.99 \\
\hline Scarlet spur & 79.64 & 74.99 & 77.31 \\
\hline Oregon spur & 70.59 & 69.03 & 69.81 \\
\hline Braeburn & 68.24 & 66.86 & 67.55 \\
\hline Ginger Gold & 73.49 & 77.56 & 75.52 \\
\hline Red Gravenstein & 68.70 & 66.54 & 67.62 \\
\hline Golden Delicious & 62.57 & 61.16 & 61.86 \\
\hline Red Gold & 62.30 & 60.44 & 61.37 \\
\hline \multicolumn{1}{|c|}{ CD (5\%) } & $\mathbf{1 . 3 5}$ & $\mathbf{1 . 3 0}$ & $\mathbf{0 . 5 9}$ \\
\hline
\end{tabular}

Table.5 Maturity of fruits under open pollination

\begin{tabular}{|l|c|c|c|}
\hline \multicolumn{1}{|c|}{ Genotypes } & \multicolumn{3}{|c|}{ Days after full bloom (DAFB) } \\
\hline Gala Must & Year 2012 & Year 2013 & Pooled \\
\hline Royal Gala & 138.00 & 142.00 & 140.00 \\
\hline Early Red One & 132.00 & 134.00 & 133.00 \\
\hline Law Red Rome & 145.00 & 147.00 & 146.00 \\
\hline Scarlet spur & 164.00 & 167.00 & 165.50 \\
\hline Oregon spur & 135.00 & 140.00 & 137.50 \\
\hline Braeburn & 139.00 & 143.00 & 141.00 \\
\hline Ginger Gold & 155.00 & 156.00 & 155.50 \\
\hline Red Gravenstein & 103.00 & 104.00 & 103.50 \\
\hline Golden Delicious & 95.00 & 96.00 & 95.50 \\
\hline Red Gold & 185.00 & 183.00 & 184.00 \\
\hline \multicolumn{1}{|c|}{ CD (5\%) } & 162.00 & 165.00 & 163.50 \\
\hline
\end{tabular}

The variety Red Gravenstein took minimum number of days (95 and 96 DAFB) to reach harvestable maturity followed by Ginger Gold (103 and 104 DAFB) during both years, respectively.

The pooled analysis of the data also revealed significant differences between all the cultivars under study with respect to the number of days taken to reach the harvestable stage.
Initial fruit set by natural self-pollination

There were non-significant differences in the fruit set during both 2012 and 2013 whereas the pooled data showed significant differences. The variations in fruit set among different varieties may be because of their genetic differences. Fruit set in temperate fruits depends upon the prevailing environment during flowering as well as the period following fruit set. In the present study 
Royal Gala, Early Red One, Scarlet spur, Ginger Gold and Red Gravenstein were completely self-incompatible as these varieties were devoid of any fruit set during both 2012 and 2013 under natural selfing. Bashir (2006) also reported selfincompatibility in Royal Gala and Fuji, which failed to set fruit when cross-pollinated with their own pollen. Sharma et al., (2005) under Nauni conditions observed Gala to be selfcompatible in 2004 but the same cultivar failed to set fruit in 2005 on selfing.

\section{Initial and final (\%) fruit set by open pollination}

Besides genetic differences, there could be an array of reasons for such differences in the initial and final fruit set among the varieties. Factors like temperature, weather conditions, atmosphere which is conducive for bee flight, pollen compatibility, mixture of pollen, effective pollination period of varieties, stigma receptivity, ovule longevity, pollen tube growth, diploid or triploid nature of varieties, post bloom temperature, stage of hand pollination, skill of emasculation during hand pollination and fertilization process contribute in fruit set. Moreover, the fruit set behavior is controlled gametophytically by a locus, which is a multigene complex; one $\mathrm{S}$ RNase gene is expressed in the pistil and one S-haplotype specific gene in the pollen tubes. Self/nonself recognition process and the consequent acceptance or rejection takes place between the protein products of these genes. Cultivars sharing common S-genotypes are mutually self-incompatible and their mating does not result a progeny. Favourable weather conditions during flowering are essential for the process of pollination and fruit set. Weather conditions during the blooming period under temperate conditions may be unfavorable for flight of pollinating insects necessary for fruit set. Honeybees in particular are less active during cold, cloudy, rainy and windy weather (Mc Gregor, 1976; Benedek 1996). Cool temperature also affects pollen tube growth and fertilization (Westwood, 1993 and Soltesz, 1996) consequently low cross-pollination levels are usually one of the yield limiting factors (Free, 1993; Dennis, 2003). The fruit set and retention obtained in the present investigation under open pollination conditions is in conformity with those reported by Tromp and Romer (1987). Similarly, the variations in fruit setting recorded under different modes of pollination in apple in the present study are in conformity with those reported by Kumar (1988) and Sharma et al., (2005).

\section{Fruit drop (percent) and maturity}

The variations in fruit drop between varieties could be due to high rates of initial fruit set which later on drop some of fruits due to poor pollination soon in the post bloom period or may be due to auto-incompatibility. This drop could be due to environmental adversities like water stress, poor nutrition etc or due to competition between fruits on the plant. It can also occur due to high temperature. According to Tylus (1975), the pre-harvest fruit drop occurs only in varieties characterized by high rates of fruit set. Wellington (1975) stated that post bloom fruit drop is due to autoincompatibility of the varieties. Teskey and Shoemaker (1972) claimed that in apple, fruit containing less than three seeds shed first when fruit set was abundant. Fruit species producing fruits containing more than one seed (apple, pear and quince) drop preferably those fruits containing less number of seeds. Such fruits are genuinely more susceptible to environmental adversities i.e. water stress, poor nutrition etc and are therefore more prone to fruit drop (Stosser, 2002). The most important precondition of the fruit to maintain on the tree is its seed content. Racsko et al., (2007), argued in favour of the effect of preceding temperature as an important factor 
responsible for June drop of apple. The present study showed that varieties attained fruit maturity in span of four months period exhibiting characters of early, mid and late season maturation under open pollination conditions. The variety reaching maturity early (95.50 DAFB) was Red Gravenstein and late maturity variety (184.00 DAFB) was Golden Delicious. The mid-season varieties Royal Gala, Scarlet spur, Gala Must, Oregon spur and Early Red One took 133.00, 137.00, $140.00, \quad 141.00$, and 146.00 DAFB respectively to reach to the maturity. The variation among cultivars in the date of maturity may be due to the difference in their genetic makeup and inherent parental characters of these varieties. These results are further supported by the findings of Karacali (2004), who reported that most important criteria in maturity of apple cultivars are duration between full bloom and harvest date, which depends upon cultivar, place, year, rootstock, and ecological conditions.

\section{References}

Alston, F.H. 1996. Incompatibility alleles and apple pollination. Acta Horticulturae 423: 119-124.

Bashir, R. 2006. Genetic Variability Heritability and intervarietal cross ability studies in apple. M.Sc Thesis submitted to Dr. Y.S. Parmar University of Horticulture and Forestry, Nauni Solan (HP), India.

Benedek, P. 1996. Insect pollination of fruit crops. In: Floral Biology of Temperate Zone Fruit Trees and Small Fruits. [Eds. J. Nyeki and M. Solestz]. Akademiai Kiado, Budapest, Hungary, pp. 287-340.

Certal, A.C., Sanchez, A.M., Kokko, H., Broothaerts, E., Oliveira, M.M. and Feijo, J.A. 1999. S-RNases in apple are expressed in the pistil along the pollen tube growth path. Sex Plant
Reproduction 12: 94-98.

Darwin, C.R. 1877. The different forms of flowers on plants of the same species, $1^{\text {st }}$ edition. London: John Murray. In: Horticultural Reviews. [Eds. J. Janick, P. Forsline, E. Dickscon, R. Way and M. Thompson], vol. 29. Wild Apple and Fruit Trees of Central Asia

De Nettancourt, D. 2001. Incompatibility and incongruity in wild and cultivated plants, $2^{\text {nd }}$ edn. Berlin: Springer-Verla

Dennis, F.G. 2003. Flowering, pollination and fruit set and development. In: Apple: Botany, Production and Uses. [Eds. D.C. Ferre and I.J. Warrington]. CABI Publishing, Wallingford, UK, pp. 153164.

Free, J.B. 1993. Insect pollination of crops $\left(2^{\text {nd }}\right.$ Edition $)$ Academia press London.

Goode, J.E. 1975. In climate and orchard (Ed. H.C. Perreira) CAB. Slough, England, pp. 51-62

Kao, T.H. and Mc Cubbin, A.G. 1996. How flowering plants discriminate between self and non-self-pollen to prevent inbreeding. Proceedings of the National Academic Science 93: 12059-12065.

Karacali, I. 2004. Storage and marketing of horticultural crops. Egypt university faculty of Agriculture Publication No: Izmir, p. 472.

Kronenberg, H.G. 1979. Apple growing potentials in Europe. The fulfillment of the cold requirement of the apple trees. Netherland Journal of Agricultural Sciences 27: 131-135.

Kumar, S. 1988. Studies on flowering pollination and fruit set in some new introduction of apple M.Sc. Thesis Dr. Y.S. Parmar University of Horticulture and Forestry, Nauni Solan (HP), India.

McGregor, S.E. 1976. Insect pollination of cultivated crop plants, US Department of Agriculture Handbook No. 496.

Racsko, J., Leite, G.B., Petri, J.L., Zhongfu, S., Wang, Y., Szabó, Z., Soltész, M. and 
Nyéki, J. 2007. Fruit drop: the role of inner agents and environmental factors in the drop of flowers and fruits. International Journal of Horticultural Science 13(3): 13-23.

Sharma, G., Roshan, A. and Sharma, O.C. 2005. Pollination deceive factor in apple productivity. In: Temperate Horticulture Current Senario. [Eds. D.K. Sharma, S.K. Sharma and K.K. Pramnick].

Sharma, G., Roshan, A. and Sharma, O.C. 2005. Pollination deceive factor in apple productivity. In: Temperate Horticulture Current Senario. [Eds. D.K. Sharma, S.K. Sharma and K.K. Pramnick].

Soltesz M 1996. Requirements for successful fruit set in orchard. In: Floral Biology of Temperate Zone Fruit Trees and Small Fruits, [Eds. J. Nyeki and M. Solestz] Akademiai kiado, Budapest, Hungary, pp. 257-286.

Stosser, R. 2002. Von der Blute zur Frucht In: Lucas' Anleitung zum Obstbau. [Ed. H. Link]. Eugen Ulmer GmbH Co., Stuttgart, pp. 29-37

Tao, R., Yamane, H., Sugiura, A., Murayama, H., Sassa, H. and Mori, H. 1999. Molecular typing of S-alleles through identification, characterization and cDNA cloning for S-RNases in sweet cherry. Journal of American Society of Horticulture Science 124: 224-233.

Teskey* and Shoemaker, 1972. In: Fruit
Drop: The Role of Inner Agents and Environmental Factors in the Drop of Flowers and Fruits. [Eds. J. Racskó, G.B. Leite, J.L. Petri, S. Zhongfu, Y. Wang, Z. Szabo, M. Soltsz and J. Nyéki, 2007]. International Journal of Horticultural Science 13(3): 13-23.

Tromp, J. and Romer, C.A.R. 1987. Temperature and fruit set in apples. Fruiteelt 77(1): 24-26.

Tylus, 1975. In: Fruit Drop: The Role of Inner Agents and Environmental Factors in the Drop of Flowers and Fruits. [Eds. J. Racskó, G.B. Leite, J.L. Petri, S. Zhongfu, Y. Wang, Z. Szabo, M. Soltsz and J. Nyéki, 2007]. International Journal of Horticultural Science 13(3): 13-23.

Wellington, 1975. In: Fruit Drop: The Role of Inner Agents and Environmental Factors in the Drop of Flowers and Fruits. [Eds. J. Racskó, G.B. Leite, J.L. Petri, S. Zhongfu, Y. Wang, Z. Szabo, M. Soltsz and J. Nyéki, 2007]. International Journal of Horticultural Science 13(3): 13-23.

Westwood, N.M. 1993. Temperate zone pomology: Physiology and culture $\left(3^{\text {rd }}\right.$ Edition) Timber Press, Portland Oregon. Westwood, N.M. 1993. Temperate zone pomology: Physiology and culture $\left(3^{\text {rd }}\right.$ Edition) Timber Press, Portland Oregon. Zohary*, D. and Hopf, M. 2000. Domestication of Plants in the Old World. Clarendon Press, Oxford.

\section{How to cite this article:}

Bilal A. Pandit, M. Ashraf Bhat, Mumtaz A. Ganie, T. Rasool and Parmeet Singh. 2018. Methods of Pollination Influencing Fruit Development Stages of Exotic Apple Cultivars at High Altitudes of Kashmir Valley. Int.J.Curr.Microbiol.App.Sci. 7(09): 2398-2406. doi: https://doi.org/10.20546/ijcmas.2018.709.298 